\title{
Assessing Consumer Purchasing Decision Styles: An Empirical Investigation From South Africa
}

Chengedzai Mafini, Vaal University of Technology, South Africa Manilall Dhurup, Vaal University of Technology, South Africa

\begin{abstract}
The determinants of how and why people shop has been a topical matter to many people for many years. This had a stimulus effect on the development and proliferation of a diversity of consumer typologies. The purpose of this study was to develop a typology of South African Generation $Y$ consumers in their purchasing decisions. The study adopted a quantitative approach in which a structured questionnaire was used to survey 294 Generation Y consumers who were selected using an integration of non-probability convenience and judgement sampling methods. Seven groups of Generation Y consumers, namely quality conscious, brand conscious, novelty seeking, hedonistic, confused by over-choice, habitual, brand loyal, and fashion conscious were identified. Differences were found between consumers who are confused by over-choice and younger Generation $Y$ consumers. Younger consumers were found to be more confused by over-choice compared to their older counterparts. Findings of this study suggest that retailers should use communication channels which would be more easily understood by Generation Y consumers, and they should provide information that assists buyers to make a rational decision in the buying process.
\end{abstract}

Keywords: Generation Y; Consumer Typology; South Africa; Purchasing Decisions

\section{INTRODUCTION}

eneration Y is a constellation of individuals who were born between 1980 and 1994 (Neal, Quester, \& Hawkins, 2004, p. 393). This generation has emerged as an important economic player in a global marketplace that is characterized by increased competition and unpredictability (Cant, Brink, \& Brijball, 2006, p. 106). There are three dominant sub-classifications of Generation Y, namely adults of 18 to 27 years of age, teenagers of 13 to 17 years of age and children of 8 to 12 years of age (Martin \& Turley, 2004, p. 464). In terms of characteristics, Generation Y consumers are said to be realistic, "savvy," enjoy surfing the Internet, avoid reading the newspaper, like to be in consistent communication with their peers, in addition to being socially and environmentally aware, and open to new experiences (Cant et al., 2006, p. 106). On the overall, they exhibit different inclinations to their parents, to the extent that they do not trust the stores that are trusted by their parents (Gonen \& Ozmete, 2006, p. 29).

\section{CONSUMER TYPOLOGIES}

Research reveals that at levels of marketing theory and practice the consumer is central to all activities. It is critical for clothing marketers to have an extensive knowledge of the various factors influencing consumers' decisions in ensuring the successful delivery of products and the retention of customers in a marketplace (Hollywood, Armstrong, \& Durkin, 2007, p. 691). Consumer typology defines general consumer types, such as price-oriented shoppers, problem-solving shoppers, impulse shoppers, and convenience shoppers (Zeng, 2008, p. 14). Leo, Bennett, and Hartel (2005, p. 33) are of the view that the consumer typology approach seeks to categorize consumers into groups or types that are related to retail patronage. The consumer typology is also associated with shopping orientation (Gehrt \& Shim, 1998, p. 35). 
Shopping orientations are shoppers' styles that place particular emphasis on certain activities (Gehrt \& Shim, 1998, p. 35). Shopping orientation is recognized as a complex social, cultural, and economic phenomenon (Lee, 1998, p. 2). Hence, the examination of a comprehensive relationship among key variables in determining shopping orientations would provide diagnostic value to retailers in determining market segmentation (Lee, 1998, $\mathrm{p}$. 3 ). The basic premise of shopping orientation is that shoppers with different orientations have different market behaviours, including a need for different information sources and different store preferences (Gehrt \& Shim, 1998, p. 36).

Westbrook and Black (1985, p. 79) identified four typologies: the economic consumer, the personalising consumer, the ethical consumer, and the apathetic consumer. Economic shoppers were characterized by a careful approach to shopping, giving heightened attention to merchandise assortment, price, and quality. Personalising shoppers appeared to seek personal relationships with retail personnel, while ethical shoppers were willing to sacrifice lower prices and wider selections of goods in order to behave consistently with moral beliefs. Finally, the apathetic shopper shops largely out of necessity, with the shopping activity holding no intrinsic interest.

Hafstrom, Chae, and Chung (1992, p. 148) examined the taxonomy of shoppers and came up with "perfectionism," "value consciousness," "brand consciousness," "novelty-fad-fashion consciousness," "shopping avoider-time saver-satisfier," and "confused support-seeking decision maker." Perfectionism consumers seek the very best quality products, have high standards and expectations for consumer goods and are concerned with the function and quality of products. Value-conscious consumers are low price conscious, look for the best value for their money and are likely to be comparison shoppers. Brand-conscious consumers are oriented toward expensive and well-known national brands and feel price is an indicator of quality. Novelty-fad-fashion conscious consumers gain excitement and pleasure from seeking out new things and are conscious of the new fashions and fads. Shopping avoider-time saver-satisfier consumers avoid shopping, make shopping trips rapidly, and they may forego some quality for time and convenience. Finally, the confused support-seeking decision-maker finds the marketplace confusing; they view brands as alike and seek help from friends (Hafstrom et al., 1992, p. 148) to make decisions.

Bae (2004, p. 4) distinguished eight characteristics of shoppers' typology: perfectionist conscious, brand conscious, novelty/fashion conscious, recreational/hedonic, price conscious/value-for-money, impulsiveness/ carelessness, confused by over-choice and habit/loyal consumers. The perfectionist/high-quality conscious consumers are aware of the desire for high quality products and the need to make the best or perfect choice versus buying the first product or brand that is available. The brand conscious consumer has the desire to purchase wellknown national brands, higher-priced brands and/or the most advertised brands. The novelty/fashion conscious consumer can be defined as a shopper who is aware of new styles, changing fashions and attractive styling, as well as having the desire to buy something exciting. The recreational/hedonic conscious consumers are shoppers who enjoy shopping as a leisure-time activity. The price conscious/consumers aspire towards the best value, buying at sale prices or the lowest price. The impulsive/careless consumers can be described as shoppers who focus on making impulsive, unplanned, and careless purchases. The confusion by over-choice consumer feels confused about product choices because of a proliferation of brands, stores, and consumer information. Finally, the habitual/brand loyalty consumers are described as consumers who have favourite brands and their buying habits reveal that they consistently use the same store over time (Bae, 2004, p. 4-6).

From the foregoing discourse, it appears that there is an assortment of consumer typologies, which is a result of the use of different bases for conceptualizing shopping orientation as well as the diversity of the retail experience and product class researched (McDonald, 1993, p. 57).

\section{PROBLEM STATEMENT}

The field of consumer behaviour has ever fascinated many people ever since the beginning of the ages (Bakewell \& Mitchell, 2003, p. 96). However, these studies have demonstrated that the behaviour of shoppers is dynamic and unpredictable (Jin \& Kim, 2003, p. 407). Also notable from previous studies is the limited attention on addressing the question of how to measure consumer decision-making styles.

Specifically, Generation Y buyers have been brought up in an era when shopping is not regarded as a simple act of purchasing (Bakewell \& Mitchell, 2003, p. 104). Generation Y consumers are likely to have developed 
a different shopping style compared to previous generations which is extremely sensitive to changes in fashion (Ma \& Niehm, 2006, p. 621; Bakewell \& Mitchel, 2003, p. 98). Despite such assertions, there have been very few studies which focused on the shopping styles of Generation Y consumers which offer guidelines to marketers and retailers on how these consumers make choices. Hence, the purpose of the study is to complement existing research on consumer purchasing decision-making orientations within the context of South Africa.

\section{PURPOSE OF THE STUDY}

The purpose of the study was to develop a typology of South African Generation Y consumers in their purchasing decisions.

\section{RESEARCH METHODOLOGY}

\section{The Target Population and Sampling Frame}

A target population is defined as the totality of cases that conform to some designated specifications (Churchill \& Iacobucci, 2005, p. 321). The population for this study included Generation Y individuals aged between 16 and 27 who were based in Gauteng Province, South Africa. This cohort was selected because individuals within this age category have the mental and cognitive capacities to respond to survey type questionnaires (Shoham \& Dalakas, 2003, p. 243) and have high buying power as well as purchasing propensities (Bakewell \& Mitchell, 2003, p. 97: Kim \& Park, 2005, p. 111). A sample frame is a master list of all the sample units within a population (Tustin, Ligthelm, Martin, \& Van Wyk, 2005, p. 342). In the current study, shopping malls and shopping centres located within Gauteng Province were used as the sampling frame.

\section{The Sampling Method and Sample Size}

A non-probability sampling procedure was employed to elicit information from 294 Generation Y individuals. Non-probability sampling relies on the personal judgement of the researcher rather than chance to select sample elements (Churchill \& Iacobucci, 2005, p. 324). The researcher can arbitrarily or consciously decide what elements to include in the sample (Dillon, Madden, \& Firtle, 1990, p. 288). The study used a combination of convenience and judgement sampling techniques (Dillon et al., 1990, p. 288). These sampling methods were adopted because they were economical and less time-consuming for the researcher to collect data.

\section{Instrumentation and Data Collection Procedures}

The study employed a self-administered survey to conduct the study. Tustin et al. (2005, p. 153) revealed that a survey is more flexible and opportunities for interviewer cheating are greatly reduced. The study used structured questionnaires to collect data and the method was chosen for its versatility, as well as the accuracy of the data, since every respondent was asked the same questions (Boyd, Westfall, \& Stasch, 1989, p. 212). The questionnaire was developed on a 5-point Likert scale, anchored with 5 denoting strongly agree, 3 denoting moderately agree, and 1 denoting strongly disagree.

Section A elicited respondents' demographic information. Section B consisted of questions related to consumer decision-making styles. The shoppers were asked to complete the questionnaires after they had completed the majority of their shopping for the day so that valid measures of the time spent "could be elicited" (Da silva, Davies, \& Naude, 2002). In order to ascertain content validity, the questionnaire was pre-tested with a convenient sample of 20 consumers. The pretesting exercise also enabled the researchers to ascertain that the questionnaire used in the main survey would validly capture the information sought by the researchers (Sudman \& Blair, 1998, p. 13). In addition, the questionnaire was also reviewed by two academics who are experts in the field of electronic marketing and information technology. This enabled the researchers to identify and eliminate problems with regard to the sequencing and wording of various questions. Feedback from the convenient sample and the experts enabled the researchers to make minor changes to the final questionnaire. The survey took place at various times of the day and on various days of the week. Trained undergraduate second-year marketing students, who were trained in fieldwork interviews, were used as research assistants. 


\section{Ethical Considerations}

Ethical considerations such as the participants' right to anonymity, confidentiality, privacy or nonparticipation, informed consent, and protection from discomfort, harm, and victimization, among others, were adhered to during the data collection process. An accompanying letter containing the names of the authors and an explanatory statement highlighting the purpose of the study was attached to the questionnaire.

\section{RESEARCH RESULTS} 20.0).

The collected data were analysed using the Statistical Packages for the Social Sciences (SPSS Version

\section{Demographic Characteristics of Respondents}

The demographic characteristics of respondents are illustrated in Table 1.

\begin{tabular}{lcccc}
\multicolumn{1}{c}{} & \multicolumn{2}{c}{ Table 1: Demographic Profile of Respondents } & \\
\hline \multicolumn{1}{c}{ Variable } & Categories & N & n & \% \\
\hline \multirow{2}{*}{ Gender } & Males & 294 & 100 & 34 \\
& Females & 294 & 194 & 66 \\
Age group & 16-20 years & 294 & 144 & 49 \\
& $21-24$ years & 294 & 103 & 35 \\
& 25-27 years & 294 & 47 & 16 \\
Race & Black & 294 & 185 & 63 \\
& White & 294 & 65 & 22 \\
& Indian & 294 & 32 & 11 \\
Highest & Coloured & 294 & 12 & 4 \\
academic & Matriculation & 294 & 50 & 17 \\
qualification & Certificate & 294 & 56 & 19 \\
& Diploma & 294 & 106 & 36 \\
& Degree & 294 & 50 & 17 \\
& Higher degree & 294 & 17 & 6 \\
\hline
\end{tabular}

The gender distribution in the sample (Table 1) indicates that out of 294 respondents, $34 \%(\mathrm{n}=100)$ were males and $66 \%(\mathrm{n}=194)$ were females. In terms of age, the 16-20 age group formed the highest percentage $(49 \%)$, followed by the 21-24 age group (35\%) and the 25-27 (16\%) age group respectively. A majority of the respondents $(49 \%: \mathrm{n}=144)$ were blacks. With regard to academic qualifications, the highest proportion of respondents $(36 \%: \mathrm{n}$ $=106$ ) were in possession of a diploma.

\section{Exploratory Factor Analysis}

The Bartlett's test of Sphericity was significant at $\mathrm{p}<0.000$ inferring that the data set is not an identity matrix with zero correlations, thus suitable for factor analysis. The KMO measure of sampling adequacy was 0.894 which is considered satisfactory by Kaiser $(1974$, p. 35), inferring that the data is suitable for factor analysis. The percentage of variance explained, the scree plot and eigen value criterion guided the extraction of factors. In addition, items that load heavily on more than one factor were eliminated from further scale development. Hence, cross-loading were also examined in the factor structure. Items were eliminated either because of cross-loading or low-factor loading $(<0.50)$. This procedure resulted in the extraction of seven meaningful factors. The names of these factors as well as their respective operational definitions are illustrated in Table 2. 
Table 2: A Typology of Generation Y Consumers

\begin{tabular}{ll}
\hline \multicolumn{1}{c}{ Factor } & \multicolumn{1}{c}{ Operational Definition } \\
\hline Habitual-conscious consumers & These are consumers who have favourite brands and stores and have formed \\
habits by choosing them repetitively (Bakewell \& Mitchell, 2004, p. 226). & These are consumers who regard quality as their major consideration when \\
& making purchase decisions (Sproles \& Sproles, 1990, p. 140; Radder, Li, \& \\
Quality-conscious consumers & Pietersen, 2006, p. 28). Quality-conscious consumers take time to shop for the \\
& best buy and purchase their favourite brands repeatedly, presumably since these \\
& represent perceived quality for them (Hiu, Siu, Wang, \& Chang, 2001, p. 334; \\
& Tai, 2005, p. 196). \\
Brand-conscious consumers & $\begin{array}{l}\text { These are consumers who are likely to purchase expensive, fashionable } \\
\text { international clothing labels because they equate higher prices with better quality }\end{array}$ \\
& (Lysonski, Durvasula, \& Zotos, 1996, p. 17; Kwan, Yeung, \& Au, 2004, p. 5; \\
Hanzaee \& Aghasibeig, 2008, p. 528). & These consumers resemble a perfectionist buyer who looks for newness in their \\
purchases, often buying the best-selling brands that are the latest in style at & expensive stores (Sproles \& Sproles, 1990, p. 141: Mokhlis, 2009, p. 143). \\
These are consumers who become confused and indecisive with regard to \\
shopping choice as the number of stores and variety in commodities increases \\
(Walsh, Mitchell, \& Hennig-Thurau, 2001, p. 85: Gonen \& Ozmete, 2006, p. 30).
\end{tabular}

\section{Reliability and Validity}

The Cronbach alpha statistic was undertaken to assess the internal consistency of the instrument (Leo et al., 2005 , p. 47). Reliability tests were conducted on all 41 items in the scale. The items that had low or negative interitem correlation were deleted. Table 3 reports on the Cronbach alpha values for the seven dimensions on Generation Y decision-making styles.

The Cronbach alpha coefficients for factors 1 to 7 ranged from 0.836 to 0.961 , indicating satisfactory levels of internal consistency in terms of reliability. The seven factors reflected the reliability values above the accepted benchmark of 0.70 , which according to Santos $(1999$, p. 2) is regarded as satisfactory. In addition, the reliability of the overall scale was 0.891 , which was also considered as satisfactory.

Table 3: Item Reliability Analysis

\begin{tabular}{lcccc}
\hline Factor Number & Name of Factor & No of items & Cronbach Alpha & \% of Variance Explained \\
\hline 1 & Habitual-conscious consumers & 3 & 0.836 & 5.13 \\
2 & Quality-conscious consumers & 5 & 0.849 & 5.41 \\
3 & Brand-conscious consumers & 6 & 0.875 & 9.28 \\
4 & Novelty-seeking consumers & 5 & 0.892 & 7.34 \\
5 & Confused by over choice consumers & 4 & 0.898 & 5.21 \\
6 & Hedonistic consumers & 8 & 0.928 & 11.2 \\
7 & Fashion-conscious consumers & 10 & 0.961 & 27.01 \\
\hline
\end{tabular}

Validity can be defined as the degree to which a test or instrument measures what it purports to measure (Bae, 2004, p. 37). Content validity was conducted in the pilot study. To test for content validity, 50 respondents were chosen to participate in the pilot study. The inter-item correlation was examined in order to identify low or negative correlations among variables that measured decision-making styles. Subsequently, changes were made to the questionnaire where several items were deleted, added, or re-worded in order to capture the essence of consumer decision-making within the context of garment retailing. Construct validity of the scale was assessed by the computation of the Cronbach alpha coefficient for the scale and sub-dimensions of the scale, which was acceptable 
and an indication of construct validity (Parasuraman, Zeithaml, \& Berry, 1988, p. 28). In addition, factor analysis was performed on each of the seven constructs to determine the percentage of variance that is explained by each factor. The results indicate that the seven factors accounted for approximately $71 \%$ of the variance explained, thus inferring construct validity (refer to Table 4).

\section{The Influence of Age}

There were significant differences in the influence of age on consumers who are confused by over-choice $(\mathrm{F}=5.18, \mathrm{p}=0.006)$. The analysis of variance (ANOVA) showed no significant differences between the remaining six factors and age. The results are reported in Table 4.

Table 4: ANOVA Confused by Over-Choice and Age

\begin{tabular}{|c|c|c|c|c|c|c|}
\hline & & Sum of squares & Df & Mean square & $\mathbf{F}$ & Sig \\
\hline (Factor 1) & Between groups & 167 & 2 & .083 & .076 & 927 \\
\hline Quality-conscious consumers & Within groups & 249.031 & 227 & 1.097 & & \\
\hline (Factor 2) & Between groups & 3.840 & 2 & 1.920 & 2.205 & .113 \\
\hline Brand-conscious consumers & Within groups & 197.627 & 227 & .871 & & \\
\hline (Factor 3) & Between groups & .492 & 2 & .246 & .351 & .704 \\
\hline Novelty-seeking consumers & Within groups & 158.996 & 227 & .700 & & \\
\hline (Factor 4) & Between groups & .618 & 2 & .309 & .328 & .721 \\
\hline Hedonistic consumers & Within groups & 214.204 & 127 & .944 & & \\
\hline (Factor 5) & Between groups & 4.945 & 2 & 2.473 & 5.180 & $.006^{*}$ \\
\hline Confused by over-choice consumers & Within groups & 108.356 & 227 & .477 & & \\
\hline (Factor 6) & Between groups & 7.599 & 2 & 3.800 & 3.123 & .056 \\
\hline Habitual, brand-loyal consumers & Within groups & 276.199 & 227 & 1.217 & & \\
\hline (Factor 7) & Between groups & 1.187 & 2 & .594 & .501 & .606 \\
\hline Fashion-conscious consumers & Within groups & 268.885 & 227 & 1.181 & & \\
\hline
\end{tabular}

Due to the existence of these differences, multiple, post hoc comparisons were conducted in order to establish among which age groups there were differences. Both the Tukey HSD as well as Bonferroni tests were used to determine group differences. The multiple post hoc comparisons are reported in Table 5.

Table 5: Multiple Post Hoc Comparisons - Confused by Over-Choice and Age

\begin{tabular}{|c|c|c|c|c|c|}
\hline Dependent Variable & I B2 (age) & J B2 (age) & Mean Difference (I-J) & Std. Error & Sig. \\
\hline \multirow{2}{*}{$\begin{array}{l}\text { Factor } 5 \\
\text { (confused by over-choice) }\end{array}$} & $\begin{array}{c}1(16-20 \text { years }) \\
(\bar{x}=4.28)\end{array}$ & $\begin{array}{c}3 \text { (25-27 years) } \\
(\bar{x}=3.94)\end{array}$ & $.3488 *$ & .1321 & .024 \\
\hline & $\begin{array}{c}2(21-24 \text { years }) \\
(\bar{x}=4.38\end{array}$ & $\begin{array}{c}3 \text { (25-27 years) } \\
(\bar{x}=3.94)\end{array}$ & .4411 & .1387 & .005 \\
\hline
\end{tabular}

Anova and Post-hoc results (Tables $4 \& 5$ ) revealed that differences exist between Factor 5 (confused by over choice) and the following age categories: 16-20 years and 25-27 years, 21-24 years and 25-27 years. Notably, consumers who were between 16 and 20 years of age $(\bar{x}=4.28)$ were found to be more confused by over-choice than those are between 25-27 years of age $(\bar{x}=3.94)$. Furthermore, respondents who were aged between 21-24 years were more confused by over-choice $(\bar{x}=4.38)$ than those who were aged between $25-27$ years $(\bar{x}=3.94)$. These results demonstrate that younger generation Y consumers are more confused by over-choice than those who are relatively older. Consistently, previous research conducted by a number of scholars (Sproles \& Sproles, 1990 , p. 142; Lysonski, Durvasula, \& Zotos, 1996, p. 17; Kim, 2003, p. 85; Hou \& Lin, 2006, p. 6) also acknowledges that younger Generation Y consumers tend to experience confusion as a result of information overload. Other authors (Bakewell \& Mitchell, 2003, p. 102; Leo et al., 2005, p. 42; Bakewell et al., 2006, p. 175; Hanzaee \& Aghasibeig, 2008 , p. 528 Leo et al., 2005, p. 42) also reported that consumers tend to be more confused because they are less likely to avoid uncertainty and more open to innovation and change, and they are likely to consider a greater range of product information and alternatives. 


\section{LIMITATIONS AND IMPLICATIONS FOR FURTHER RESEARCH}

The study has limitations in that a small sample size of 294 respondents, which makes it difficult to generalise the results to other populations and contexts. The use of non-probability techniques also enhanced the study's susceptibility to sampling bias. The questionnaire used in the study was adapted from other studies which had different purposes. Additionally, the study concentrated on Generation Y consumers who were in the age range of 16 to 27 years old in order to assess and analyze their behaviour concerning fashion garments decision-making. In view of this, future research should accommodate other generational cohorts so that valuable insights may be obtained to segment markets and to develop appropriate marketing communication strategies.

Since the study made use of a quantitative research design, future research may consider both a qualitative and quantitative analysis using the triangulation methodology, in which a qualitative design could be used to analyze the personality of Generation Y consumers and their buying behaviour. Future researchers could replicate the study in other provinces and countries in order to test the relevance and reliability of the scale. More research studies focusing on consumer decision-making styles representing ethnic cultures from different provinces of South Africa might produce interesting findings.

\section{CONCLUSIONS}

The purpose of this study was to develop a typology of South African Generation Y consumers in their purchasing decisions. Findings of the study indicate that Generation Y consumers are quality conscious, brand conscious, novelty seekers, hedonistic, confused by over-choice, habitual, brand loyal, and fashion conscious. The age of Generation Y consumers had an impact on the 'confused by over-choice' factor. This finding is denotative of the fact that younger Generation consumers are more confused in their purchase choices than the older Generation $\mathrm{Y}$ consumers.

The current study has research and managerial implications. To researchers, the study provides information on a how Generation Y consumers may be classified. That being the case, researchers may use the findings of the current study as a benchmark and referencing tool in future studies on the behaviour of Generation Y consumers. To marketers, the study enhances the understanding of the purchasing behaviour of Generation Y consumers. Retailers can therefore use the findings of the study in their day to day decision-making in order to provide the right products as well as to boost the sales of these products.

\section{AUTHOR INFORMATION}

Chengedzai Mafini, Ph.D., is a lecturer in the Faculty of Management Sciences at Vaal University of Technology, South Africa. His research interests are centered on business management disciplines such as marketing and human resources. He is a published author in several journals and has also presented a number of papers at various international conferences. He is currently involved in the supervision of a number of master's degree students at Vaal University of Technology. E-mail: chengedzai@ hotmail.com (Corresponding author)

Manilall Dhurup, Ph.D., Professor, is the Executive Dean in the Faculty of Management Sciences at the Vaal University of Technology, South Africa. His research interests include marketing and sport marketing, consumer behaviour, human resources, and consumer behaviour. He has published widely in academic journals and supervised numerous students' at master's and doctoral levels. In addition he sits in various research and innovation committees and runs the post graduate induction programme for master's and doctoral students. E-mail: royd@vut.ac.za

\section{REFERENCES}

1. Bae, S. (2004). Shopping pattern differences of physically active Korean and American university consumers for athletic apparel. (PhD. Unpublished Thesis). The Florida State University College of Education, Florida.

2. Bakewell, C., \& Mitchell, V. W. (2003). Generation Y female consumer decision-making styles. International Journal of Retail \& Distribution Management, 3(2), 95-106. 
3. Bakewell, C., \& Mitchell, V. W. (2004). Male consumer decision-making styles. International Review of Retail, Distribution and Consumer Research, 14(2), 223-240.

4. Bakewell, C., Mitchell, V. W., \& Rothwell, M. (2006). UK Generation Y male fashion consciousness. Journal of Fashion Marketing and Management, 10(2), 169-180.

5. $\quad$ Cant, M., Brink, A., \& Brijball, S. (2006). Consumer behaviour $\left(2^{\text {nd }}\right.$ ed.). Cape Town: Juta and Co.

6. Churchill, G. A., \& Iacobucci, D. (2005). Marketing research: Methodological foundation ( $9^{\text {th }}$ ed.). New York: Thomson South-Western Publisher.

7. Da Silva, R., Davies, G., \& Naude, P. (2002). Assessing the influence of retail buyer variables on the buying decision-making process. European Journal of Marketing, 36(11/12), 1327-1343.

8. Dillon, W. R., Madden, T. J., \& Firstle, N. H. (1990). Marketing research in a marketing environment $\left(2^{\text {nd }}\right.$ ed.). New York: Donnelly \& Sons Company.

9. Gehrt, K. C., \& Shim, S. (1998). A shopping orientation's segmentation of French consumers: Implications for catalog marketing. Journal of Interactive Marketing, 12(4), 34-46.

10. Gonen, E., \& Ozmete, E. (2006). Decision-making styles of young Turkish consumers. Journal of the Home Economics, Institute of Australia, 13(1), 26-33.

11. Hafstrom, J. L., Chae, J. S., \& Chung, Y. S. (1992). Consumer decision-making styles: Comparison between United States and Korean young consumers. The Journal of Consumer Affairs, 26(1), 146-158.

12. Hanzaee, K. H., \& Aghasibeig, S. (2008). Generation Y female and male decision-making styles in Iran. Distribution and Consumer Research, 18(5), 521-537.

13. Hiu, A., Siu, N., Wang, C. C. L., \& Chang, L. M. K. (2001). An investigation of decision-making styles of consumers in China. Journal of Consumer Affairs, 35(2), 326-345.

14. Hollywood, L. E., Armstrong, G. A., \& Durkin, M. G. (2007). Using behavioural and motivational thinking in food segmentation. International Journal of Retail \& Distribution Management, 35(9), 691-702.

15. Hou, C., \& Lin, Z. H. (2004). Shopping styles of working Taiwanese females. National Chung Cheng University running paper. Taiwan, 1-8.

16. Jin, B., \& Kim, J. O. (2003). A typology of Korean discount shoppers: Shopping motives, store attributes, and outcomes. International Journal of Service Industry Management, 14(4), 396-419.

17. Kaiser, H. F. (1974). An index of factorial simplicity. Psychometrike, 29(1), 31-36.

18. Kim, J., \& Park, J. (2005). A consumer shopping channel extension model: Attitude shift toward the online store. Journal of Fashion Marketing and Management, 9(1), 106-121.

19. Kim, J. (2003). College students' apparel impulse buying behaviours in relation to visual merchandising. (Unpublished M Tech. Thesis). American Intercontinental University, Los Angeles.

20. Kwan, C. Y., Yeung, K. W., \& Au, K. F. (2004). Decision-making behaviour toward casual wear buying: A study of young consumers in mainland China. Journal of Management \& World Business Research, 1(1), $1-10$.

21. Lee, J. (1998). Shopping orientations, purchase criteria and consumption patterns as an outcome of the acculturation process among female Korean-American consumers. (PhD. Unpublished Thesis). University of Texas Tech, Texas.

22. Leo, C., Bennett, R., \& Hartel, C. E. J. (2005). Cross-cultural differences in consumer decision-making styles. Cross-Cultural Management, 12(3), 32-62.

23. Lysonski, S., Durvasula, S., \& Zotos, Y. (1996). Consumer decision-making styles: A multi-country investigation. European Journal of Marketing, 30(12), 10-21.

24. Ma, Y. J., \& Niehm, L. S. (2006). Service expectation of older generation Y customers: An examination of apparel retail setting. Journal of Managing Service Quality, 16(6), 620-640.

25. Martin, C. A., \& Turley, L. W. (2004). Malls and consumption motivation: An exploratory examination of older Generation Y consumers. International Journal of Retail \& Distribution Management, 32(9), 464475.

26. McDonald, W. J. (1993). The roles of demographics purchase histories, and shopper decision-making styles in predicting consumer catalog loyalty. Journal of Direct Marketing, 7(3), 55-64.

27. Mokhlis, S. (2009). An investigation of consumer decision-making styles of young-adults in Malaysia. International Journal of Business and Management, 4(4), 140-155.

28. Neal, C., Quester, P., \& Hawkins, D. J. (2004). Consumer behaviour: Implications for marketing strategy ( $6^{\text {th }}$ ed.). Sydney: McGraw-Hill. 
29. Parasuraman, A., Zeithaml, V., \& Berry, L. (1988). A multiple-item scale for measuring customer perceptions of service quality. Journal of Retailing, 64(1), 12-40.

30. Radder, L., Li, Y., \& Pietersen, J. J. (2006). Decision-making styles of young Chinese, Motswana and Caucasian consumers in South Africa: an exploratory study. Journal of Family Ecology and Consumer Sciences, 34, 20-31.

31. Santos, J. R. A. (1999). Chronbach's Alpha. A tool for assessing the reliability of scale. 37(2).2009. Retrieved November 12, 2012 from http://www.joe.org/joe/1999.april/tt3

32. Shoham, A., \& Dakalas, V. (2003). Family consumer decision making in Israel: The role of teens and parents. Journal of Consumer Marketing, 20(3), 238-251.

33. Sproles, E. K., \& Sproles, G. B. (1990). Consumer decision-making styles as a function of individual learning Styles. The Journal of Consumer Affairs, 24(1), 134-147.

34. Sudman, S., \& Blair, E. (1998). Marketing research: A problem solving approach. Boston: McGraw-Hill.

35. Tai, S. H. C. (2005). Shopping styles of working Chinese females. Journal of Retailing and Consumer Services, 12(3), 191-203.

36. Tustin, D. H., Ligthelm, A. A., Martin, J. H., \& Van Wyk, H. D. J. (2005). Marketing research (1 ${ }^{\text {st }}$ ed.). Cape Town: University of South Africa press.

37. Walsh, G., Mitchell, V. W., \& Hennig-Thurau, T. H. (2001). German consumer decision-making styles. The Journal of Consumer Affairs, 35(1), 73-95.

38. Westbrook, R. A., \& Black, W. C. (1985). A motivation-based shopper typology. Journal of Retailing, 61(1), 78-103.

39. Zeng, Y. (2008). An investigation of decision-making styles of Chinese college student online apparel shoppers. (Master's degree. Unpublished Thesis). Louisiana State University and Agricultural and Mechanical College, Louisiana. 
NOTES 